\title{
THE HYDROLYSIS OF THE THREE CLUPEIN COMPONENTS BY SUBTILISIN NOVO, SUBTILISIN CARLSBERG AND NITRATED SUBTILISIN CARLSBERG
}

\author{
by \\ IB SVENDSEN \\ Department of Chemistry, Carlsberg Laboratory \\ Gamle Carlsberg Vej 10 - DK-2500 Copenhagen, Valby
}

Key words: Clupein, subtilisin, proteolysis.

\begin{abstract}
The three components of clupein ( $Y^{1}, Y^{11}$ and $Z$ ) were hydrolyzed by subtilisin Carlsberg and subtilisin Novo. Subtilisin Novo hydrolyzed all three components much faster than did subtilisin Carlsberg, but components $\mathrm{Y}^{11}$ and $\mathrm{Z}$ were hydrolyzed with the same initial rate and faster than component $\mathrm{Y}^{\mathrm{l}}$. The primary bonds cleaved in component YII were $\operatorname{Ser}_{22}-\operatorname{Arg}_{23}$ followed by $\mathrm{Ala}_{8}-\mathrm{Ser}_{9}$. $\operatorname{Ser}_{21}-\mathrm{Arg}_{22}$ followed by $\mathrm{Ala}_{9}-\mathrm{Ser}_{10}$ were the primary bonds cleaved in clupein-Z. It was further demonstrated that nitrated subtilisin Carlsberg had become more specific for cleavage of the Ser-Arg bond compared with the unmodified enzyme. With clupein $Y^{1}$ as the substrate, the peptide pattern obtained was too complicated for a particular bond to be identified as the primary attacking point for the two unmodified enzymes. Nitrated subtilisin Carlsberg attacked initially the bonds $\mathrm{Arg}_{5}-\mathrm{Ser}_{5}$ and $\mathrm{Ser}_{6}-\mathrm{Ser}_{7}$.
\end{abstract}

\section{INTRODUCTION}

Clupein sulfate (a protamine isolated from herring sperms) is a good substrate for subtilisin Novo (10). Subtilisin Carlsberg degrades this substrate 8 to 10 times slower, primarily due to weaker binding (11). However, nitration of
$\mathrm{Tyr}_{104}$ in subtilisin Carlsberg increases the rate of hydrolysis of clupein sulfate to the same level as with subtilisin Novo (17). This finding was explained by the introduction of a negative charge in a secondary binding site, $\mathrm{S}_{4}{ }^{1}$, on subtilisin Carlsberg, a site which most likely will contain

1. The subsite nomenclature of SCHECHTER and BERGER (14) has been adopted in the present paper for the description of the binding of substrates to the subtilisins. 
Tyr $_{104}$. KRAUT and coworkers (13) have shown from X-ray crystallographic studies that $\mathrm{Tyr}_{104}$ was part of subsite $S_{4}$ in subtilisin BPN' (identical to subtilisin Novo). Although the detailed three-dimensional structure of the Carlsberg enzyme has yet to be published, it is almost certain that $\mathrm{Tyr}_{104}$ also is part of $\mathrm{S}_{4}$ in this enzyme since the two enzymes are highly homologous (20). A model of subtilisin Carlsberg built in our laboratory on the basis of the coordinates for subtilisin BPN' is also compatible with $\mathrm{Tyr}_{104}$ being part of subsite $\mathrm{S}_{4}$. The objects of the present study were to locate the bonds initially cleaved in clupein by subtilisin Carlsberg and subtilisin Novo, and to determine if the same bonds are hydrolyzed by nitrated subtilisin Carlsberg. Since the sequences of the three components of clupein $\left(\mathrm{Y}^{\mathrm{I}}, \mathrm{Y}^{\mathrm{II}} \text { and } \mathrm{Z}\right)^{2)}$ are known (1) it is possible to compare the results with the three-dimensional models of the subtilisins, and to check if they are compatible with the binding mode for peptides proposed by KRAUT and coworkers (13). Since clupein does not contain any of the amino acid residues Tyr, Leu or Phe, which from the studies of MORIHARA and coworkers (7) are expected to bind preferentially in $S_{1}$, this particular polypeptide is well suited for the study of the secondary binding sites in the subtilisins.

Finally, the rate of hydrolysis of the individual clupein components has been studied in order to determine if one of the components was hydrolyzed much faster than the two others and consequently would determine the initial rate of hydrolysis of unfractionated clupein.

\section{MATERIALS AND METHODS}

\subsection{Materials}

Subtilisin Novo (Batch 120-4) and subtilisin Carlsberg (Batch 70-3) were gifts from Novo Industries, Copenhagen, Denmark. Nitrated subtilisin Carlsberg containing 5.8 moles of nitrotyrosine per mole of enzyme was prepared as described by SVENDSEN (17).

\subsection{Preparation of the individual clupein compo- nents}

Clupein sulfate was prepared from dried herring sperms essentially as described by SCHMiedeberg (15). This preparation consists of three polypeptide chains in almost equal amounts but with different amino acid composition. Further separation into the individual chains was achieved by the method of ANDO (2), scaled up to handle $2 \mathrm{~g}$ quantities. A Biogel $\mathrm{CM}-2$ column $(2.6 \times 100 \mathrm{~cm})$ was equilibrated with a $0.05 \mathrm{M}-\mathrm{Na}$-acetate buffer, $\mathrm{pH} 5.8$, containing $1.5 \mathrm{M}$ of $\mathrm{NaCl}$ and $0.02 \% \mathrm{NaN}_{3} .2 \mathrm{~g}$ clupein sulfate was dissolved in $50 \mathrm{ml}$ of the same buffer and centrifuged to remove a small amount of undissolved material. The clear supernatant was applied on the top of the column, and the elution performed with the same buffer. The flow-rate was $14.5 \mathrm{ml} / \mathrm{hr}$, and fractions of $10 \mathrm{ml}$ were collected. The fractionation was made at room temperature due to the poor solubility of clupein sulfate at $4^{\circ}$. The three clupein containing peaks were located by the Sakaguchi reaction (5), pooled individually, dialyzed extensively against distilled water and lyophilized. Although the molecular weight of clupein is only about 4000 daltons, complete recovery of material in the dialysis step was achieved. The isolated components were obtained as the chloride salts. These are very hygroscopic, as opposed to clupein sulfate, and were stored in a vacuum desiccator.

\subsection{Kinetic experiments}

Kinetic experiments were conducted in a $\mathrm{pH}$ stat (Radiometer titrator TTT2, equipped with a syringe burette, type SBU 10). Two $\mathrm{ml}$ of clupein $(0.1-0.5 \%)$ was brought to $30^{\circ}$ in the water-jacketed pH-stat vessel and a suitable amount of enzyme added in a small volume (25 or $50 \mu \mathrm{l})$. The base-uptake $(0.02 \mathrm{M}-\mathrm{NaOH})$ was recorded on a Radiometer Titrigraph SBR2b and the initial rate of reaction calculated from the slope of the tangent to the curve through the starting point.

2. The nomenclature of ANDo (1) has been used to describe the three clupein components. 


\subsection{Separation of hydrolytic peptides}

Two $\mathrm{ml}$ of a $0.5 \%$ solution of clupein $\mathrm{Y}^{\mathrm{I}}$, $\mathrm{Y}^{\mathrm{Il}}$ or $\mathrm{Z}$ were hydrolyzed in the $\mathrm{pH}$-stat by subtilisin Carlsberg, nitrated subtilisin Carlsberg or subtilisin Novo until an uptake of $2 \mu \mathrm{eq} . \mathrm{NaOH}$ had been recorded. $\mathrm{HCl}$ ( $1 \mathrm{M})$ was added, quickly lowering the $\mathrm{pH}$ to about two, and the solution was left for $10 \mathrm{~min}$ to denature the enzyme. The solution was then transferred to a flask, lyophilized and redissolved in $1 \mathrm{ml}$ of a $0.05 \mathrm{M}$-Na-acetate buffer, $\mathrm{pH}$ 5.8. $50 \mu \mathrm{l}$ were withdrawn for amino acid analysis to determine the amount subsequently applied to the ion-exchange column. This was carboxymethyl cellulose $(0.9 \times 52 \mathrm{~cm}$, Whatman $\mathrm{CM} 52)$, equilibrated with a $0.05 \mathrm{M}-\mathrm{Na}$-acetate buffer, $\mathrm{pH}$ 5.8. Elution of the peptides was done at room temperature with a linear gradient made from $110 \mathrm{ml} 0.05 \mathrm{M}-\mathrm{Na}$-acetate, $\mathrm{pH} 5.8+0.5$ $\mathrm{M}-\mathrm{NaCl}$ in the first chamber, and $110 \mathrm{ml} 0.05$ M-Na-acetate, pH $5.8+1.5 \mathrm{M}-\mathrm{NaCl}$ in the second chamber of the gradient mixer. Both buffers contained $0.02 \% \mathrm{NaN}_{3}$. The flow-rate was $15 \mathrm{ml} / \mathrm{hr}$ and fractions of $2.5 \mathrm{ml}$ were collected. The eluted peaks were located by the Sakaguchi reaction (5). The individual peaks were pooled and after thorough mixing a suitable aliquot was withdrawn for amino acid analysis.

\subsection{Amino acid analysis}

Hydrolyses were made in constant boiling $\mathrm{HCl}$ at $110^{\circ}$ for $24 \mathrm{hrs}$ in sealed evacuated tubes. The hydrolyzed samples were dried in a $40^{\circ}$ water-bath under a stream of air. The amino acid analyses were done on an amino acid analyzer, Durrum Model 500, according to the procedure given by the manufacturer.

\section{RESULTS}

\subsection{Separation of clupein components}

As shown in Fig. 1 a good separation of the three components in clupein sulfate, prepared according to SCHMIEDEBERG (15), was achieved. The components emerged in the following order: $\mathrm{YII}^{\mathrm{II}} \mathrm{Y}^{\mathrm{l}}$ and $\mathrm{Z}$. Since the clupein reported by ANDO was isolated from the Pacific herring and not the Atlantic herring, as was the case in the present study, the possibility of small

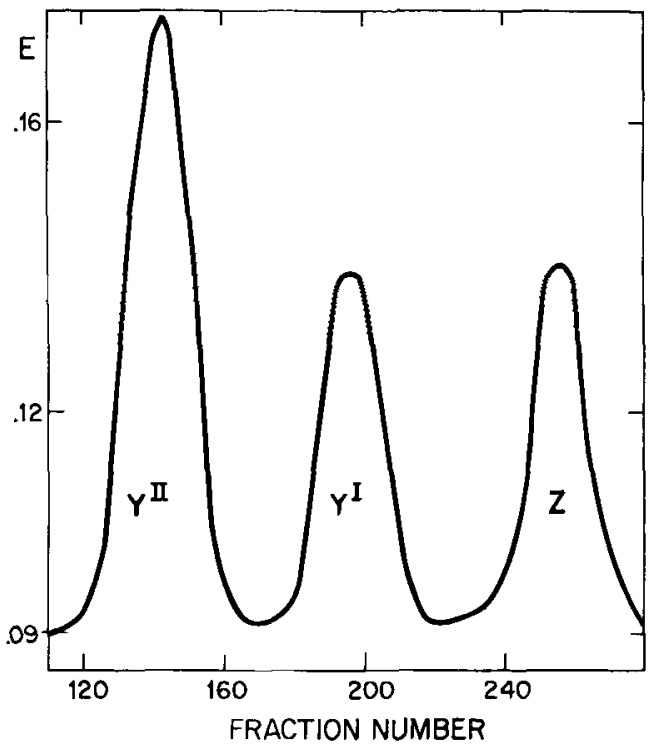

Figure 1. Fractionation of clupein on Biogel CM-2 $(2.6 \times 100 \mathrm{~cm})$. Elution buffer: Na-acetate $(0.05 \mathrm{M})$ $\mathrm{pH} 5.8+1.5 \mathrm{M}-\mathrm{NaCl}+0.02 \% \mathrm{NaN}_{3}$. Flow-rate: 15 $\mathrm{ml} / \mathrm{hr}$. Fractions of $5 \mathrm{ml}$ were collected. Room-temperature. Ordinate: $E_{520 \mathrm{~nm}}$, abscisse: fraction number.

differences in amino acid composition exists. However, the amino acid analyses on the three components agreed well with those reported by ANDO. Differences in the sequences cannot be finally excluded before sequence determinations have been performed on the clupeins from the Atlantic herring, but in those cases where clean peptides were obtained after hydrolysis with the subtilisins no difficulty was found in fitting the amino acid composition to fragments of clupein according to the sequence given by ANDO. The interpretation of the results in the present paper rests on the assumption that identity in sequence exists between the clupeins isolated from the Pacific and the Atlantic herring, respectively.

\subsection{Kinetic studies}

The rate of hydrolysis of increasing concentrations of clupein $\mathrm{Y}^{\mathrm{I}}, \mathrm{Y}^{\mathrm{II}}$ and $\mathrm{Z}$ by subtilisin Carlsberg and subtilisin Novo was studied. It has been shown previously (11) that addition of $0.1 \mathrm{M}-\mathrm{NaCl}$ to the medium has only a minor effect on the hydrolysis of unfractionated clupein sulfate, and the first series of ex- 


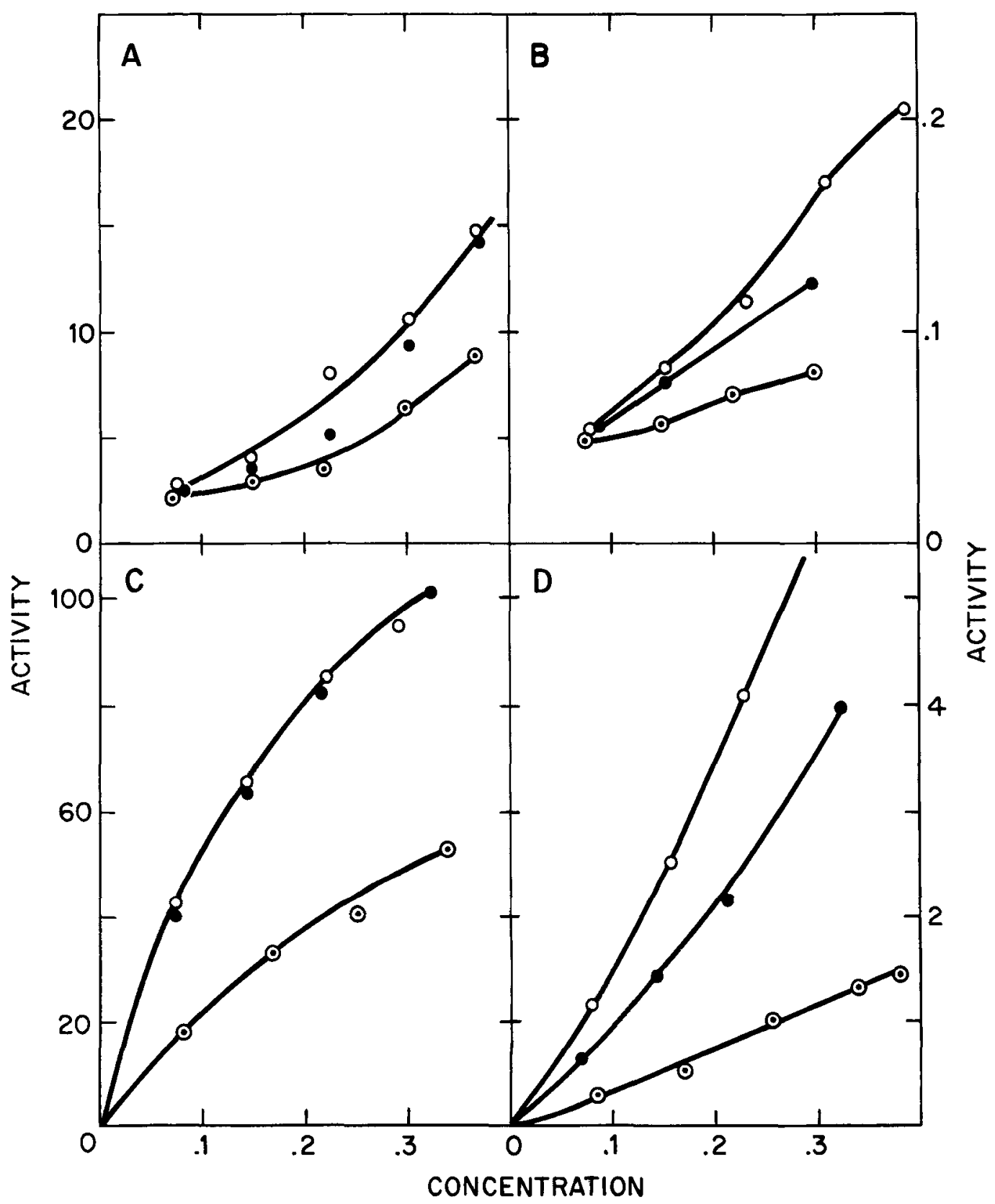

Figure 2. The hydrolysis of clupein YI (-O- ), Yll $\left(-\mathrm{O}^{-}\right)$and $\left.Z(-)_{-}\right)$by subtilisin Novo and subtilisin Carlsberg. Abscisse: clupein concentration in per cent. Ordinate: rate of hydrolysis expressed as $\mu$ eq. $\mathrm{H}+/ \mathrm{min} / \mathrm{mg}$ enzyme $/ \mathrm{ml}$ in a $2 \mathrm{ml}$ reaction mixture, at $\mathrm{Ph} 8,0$ and $30^{\circ}$. A and $\mathrm{C}$ : digestion with subtilisin Novo in distilled water (A) and $0.1 \mathrm{M}-\mathrm{NaCl}$ (C). B and $\mathrm{D}$ : digestion with subtilisin Carlsberg in distilled water (B) and $0.1 \mathrm{M}-\mathrm{NaCl}$ (D). periments with the fractionated clupein chlorides was accordingly carried out in destilled water. However, the observed rates of hydrolysis, Fig. 2 (A and B) were much smaller than would be expected from the earlier experiments with unfractionated clupein sulfate, although the marked difference in efficiency of the two enzymes persisted, subtilisin Novo being the more effective. Clupein $\mathrm{YII}$ and $\mathrm{Z}$ were 
hydrolyzed with identical rates by subtilisin Novo. Since the amino acid sequences of these clupeins are nearly identical, the result suggested that the initial attack by the enzyme took place in the part of the polypeptide which was identical in the two components. $\mathrm{Y}^{\mathrm{I}}$ was hydrolyzed with a slower rate than the two other components. Similar results were obtained with subtilisin Carlsberg. $\mathrm{Y}^{\mathrm{I}}$ was hydrolyzed with the slowest rate, but the Zcomponent was also hydrolyzed more slowly than $\mathrm{YII}^{\mathrm{II}}$ (Fig. 2 (A and B)).

Since these experiments were performed with clupein chlorides rather than sulfates, they were repeated with $0.1 \mathrm{M}-\mathrm{NaCl}$ added to the medium to test if the slow reaction-rate observed without added salt originated from electrostatic repulsions. The screening effect of $0.1 \mathrm{M}-\mathrm{NaCl}$ is demonstrated in Fig. 2 (C and $D)$. The rate of hydrolysis of $\mathrm{Y}^{\mathrm{II}}$ and $Z$ increased to the same level as found with unfractionated clupein sulfate, and the shapes of the curves also changed (compare with Fig. 2 (A and $B)$ ). $K_{M}(a p p)$, calculated for the subtilisin Novo-Yll or $-Z$ complex from a Lineweaver-Burk plot, was $7 \times 10^{-4} \mathrm{M}$ in good agreement with $8 \times 10^{-4} \mathrm{M}$ calculated for clupein sulfate (11). In this case, $\mathrm{Y}^{\mathrm{I}}$ was also hydrolyzed slower than the two other components by both enzymes, and on a relative basis the enhancement of rate was less than for components $\mathrm{Y}^{\mathrm{II}}$ and $\mathrm{Z}$.

That the nature of the counter-ion determined whether extra salt had to be added in order to maintain the usual rate of hydrolysis was demonstrated by two additional experiments. In the first experiment, unfractionated clupein sulfate was dialyzed against $\mathrm{NaCl}$ followed by dialysis against deionized water. The rate of hydrolysis decreased to the level shown in Fig. 2 ( $A$ and $B$ ). In the second experiment, the fractionated clupeins were dialyzed against $\mathrm{Na}_{2} \mathrm{SO}_{4}(0.1 \mathrm{M})$ followed by dialysis against deionized water ${ }^{3}$. The rate of hydrolysis was now increased to the level obtained with clupein chloride $+0.1 \mathrm{M}-\mathrm{NaCl}$.

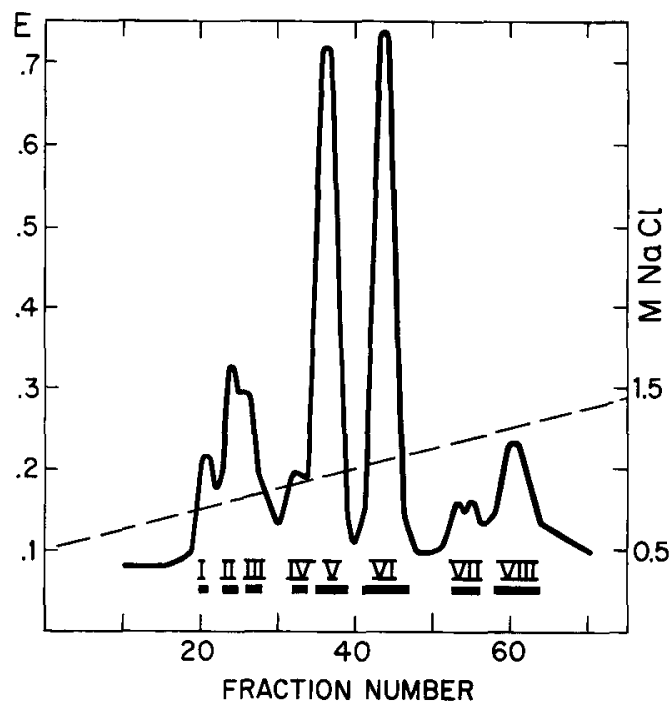

Figure 3. Chromatography of clupein YII, digested with subtilisin Novo, on Whatman CM $52(\mathrm{I} \times 60 \mathrm{~cm})$. Elution buffers: $110 \mathrm{ml} 0.05 \mathrm{M}$-acetate buffer, pH 5.8 $+0.5 \mathrm{M}-\mathrm{CaCl}$ and $110 \mathrm{ml} 0.05 \mathrm{M}$-acetate buffer $\mathrm{pH}$ $5.8+1.5 \mathrm{M}-\mathrm{NaCl}$. Both buffers contained $0.02 \%$ $\mathrm{NaN}_{3}$. Fractions of $2.5 \mathrm{ml}$ were collected. Flow-rate $15 \mathrm{ml} / \mathrm{hr}$. Room-temperature.

- - - - salt-gradient. - fractions pooled for further analysis. Left ordinate: $\mathrm{E}_{520 \mathrm{~nm}}$. right ordinate: $\mathrm{NaCl}$ conc. (M), abscisse: fraction number.

\subsection{Identification of hydrolyzed bonds}

\subsubsection{Clupein $Y^{I l}$}

When clupein $\mathrm{Y}^{\mathrm{II}}$ was digested with subtilisin Novo and subjected to ion-exchange chromatography, the elution pattern shown in Fig. 3 was obtained. Of the 8 recognizable peaks I, IV and VII were not identifiable with any part of the Yll chain. However, on the basis of amino acid recovery it was calculated that the three unidentified peaks only amounted to $8-9 \%$ of the total recovery of amino acids. Since the purpose of this part of the study was to determine the initial bonds attacked by the subtilisins, no further attempts were made to identify the peaks which contributed only little to the overall yield.

As expected from chromatography of unhydrolyzed $\mathrm{Y}^{\mathrm{II}}$, peak VIII consisted of $\mathrm{Y}^{\mathrm{II}}$. Two peaks, $\mathrm{V}$ and VI, were identified as $\mathrm{Pro}_{1}-\mathrm{Ser}_{21}$

3. In this case the dialysis bag became partly penetratable to clupein. Total recovery, however, was observed when clupein sulfate was dialyzed against $\mathrm{NaCl}$. In both cases the concentration was estimated from amino acid analysis. 


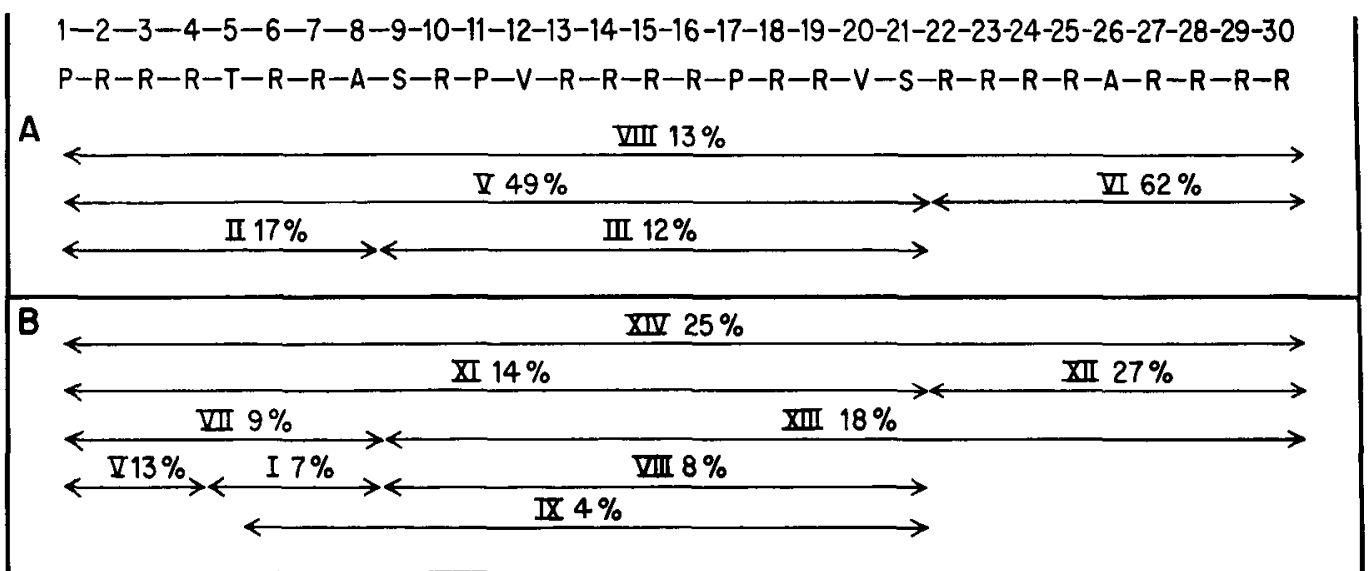

Figure 4. Compositions and yields (In per cent of material applied to the Whatman CM-52 column) of the peptide fragments from digest of clupein $Y^{11}$ by A) subtilisin Novo, B) subtilisin Carlsberg. $\mathrm{T}=\mathrm{Thr}$, $\mathrm{S}=$ Ser, $\mathrm{P}=$ Pro, $\mathrm{G}=$ Gly, $\mathrm{A}=\mathrm{Ala}, \mathrm{V}=$ Val, $\mathrm{I}=\mathrm{Ile}$ and $\mathrm{R}=\mathrm{Arg}$.

Figure 5. Chromatography of clupein YII, digested with subtilisin Carlsberg, on Whatman CM52 $(1 \times 60$ $\mathrm{cm}$ ). Elution buffer $0.05 \mathrm{M}$-acetate buffer, pH 5.8 , $0.02 \% \mathrm{NaN}_{3}$. Salt gradients: 1) 0-0.5 M-NaCl (220 ml) 2) $0.5-1.5 \mathrm{M}-\mathrm{NaCl}(220 \mathrm{ml})$. Fractions: $2.5 \mathrm{ml}$. Flowrate: $15 \mathrm{ml} / \mathrm{hr}$. Left ordinate: $\mathrm{E}_{520 \mathrm{~nm}}$, right ordinate: $\mathrm{NaCl}$ conc. (M). Abscisse: fraction number. . - salt gradient. - Fractions pooled for further analysis. and $\operatorname{Arg}_{22}-\operatorname{Arg}_{30}$, respectively, as indicated in Fig. 4, A. Peak II was found to be $\mathrm{Pro}_{1}-\mathrm{Ala}_{8}$, and peak III was $\operatorname{Ser}_{9}-\operatorname{Ser}_{21}$. The per cent recovery of hydrolytic peptides based on the amount of digest applied to the column is shown in Fig. 4, A. The bond $\operatorname{Ser}_{21}-\operatorname{Arg}_{22}$ is the first one to be hydrolyzed by subtilisin Novo, followed by $\mathrm{Ala}_{8}-\mathrm{Ser}_{9}$.

When YII was hydrolyzed by subtilisin Carlsberg, a chromatogram similar to the one shown in Fig. 3 was obtained after ionexchange chromatography. However, several overlapping small peaks were located between

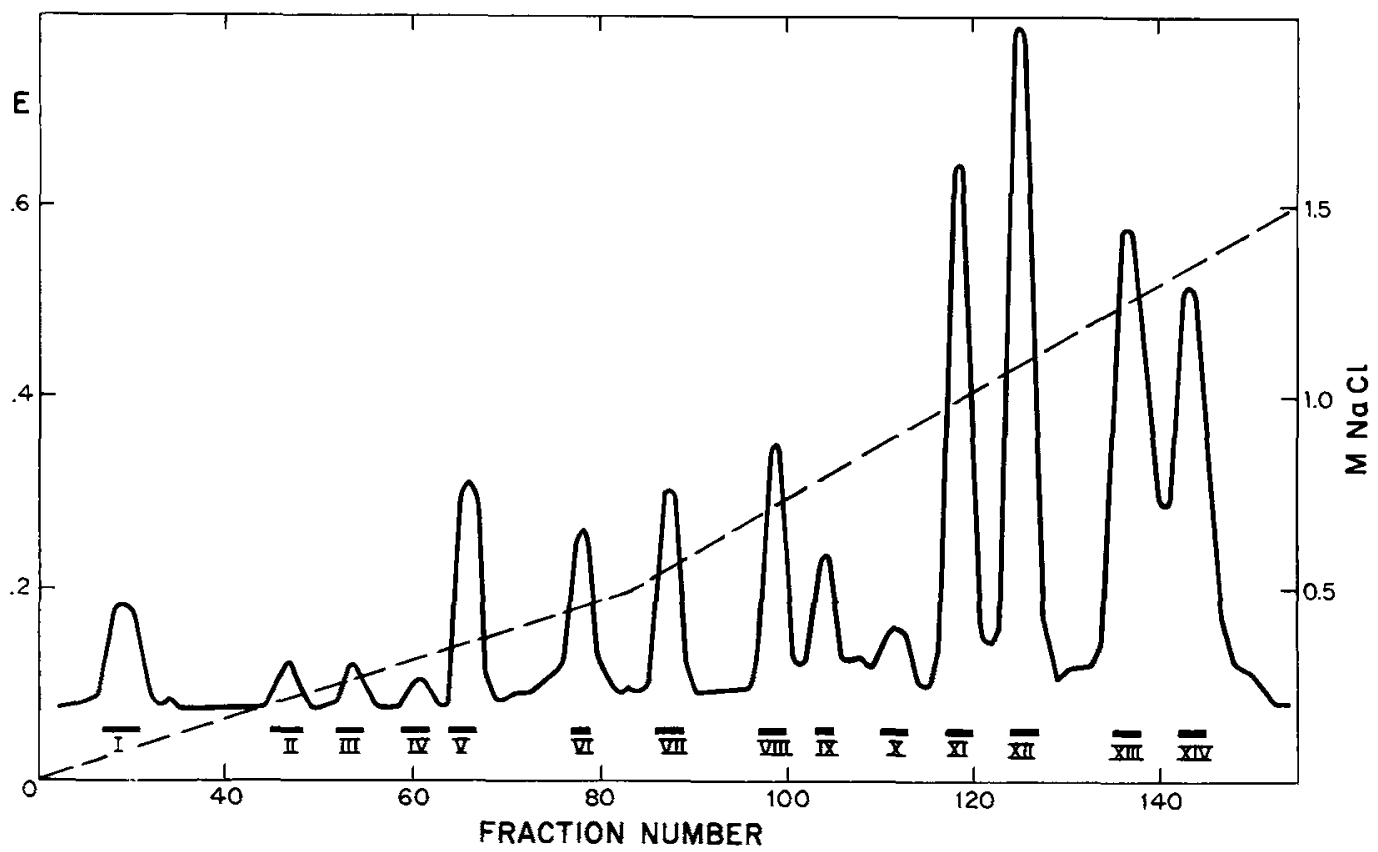




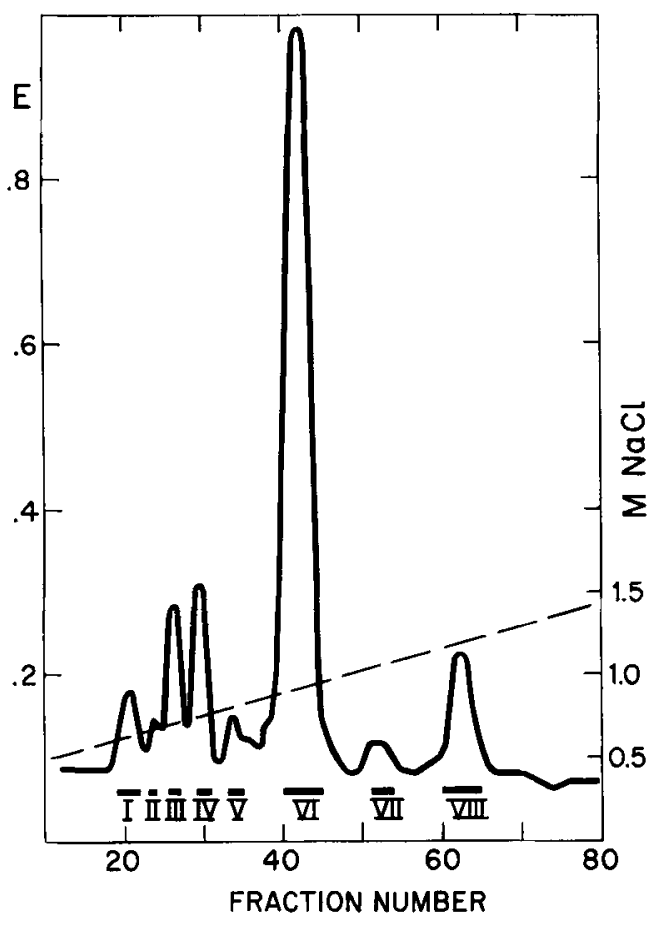

Figure 6. Chromatography of clupein $\mathrm{Z}$, digested with subtilisin Novo, on Whatman CM $52(1 \times 60 \mathrm{~cm})$. Same conditions as in Figure $\mathrm{C}$.

Figure 7. Compositions and yields (in per cent of material applied to the Whatman CM 52 column) of peptide fragments from digests of clupein- $Z$ with $A$ ) subtilisin Novo, B) subtilisin Carlsberg, C) nitrated subtilisin Carlsberg. peaks I and IV. In order to obtain a better separation of these peaks, the elution was started with a salt gradient ranging from 0 to 0.5 $\mathrm{M}-\mathrm{NaCl}$ followed by the usual gradient ranging from 0.5 to $1.5 \mathrm{M}-\mathrm{NaCl}$. The resulting elution pattern is shown in Fig. 5.

The majority of the peaks were identified with known sequences, and their position in the cromatogram together with the yields in which they were isolated are shown in Fig. 4, B. It is seen that the bonds $\operatorname{Ser}_{21}-\operatorname{Arg}_{22}$ and $\mathrm{Ala}_{8}-\operatorname{Ser}_{9}$ are hydrolyzed with almost equal rates in contrast to what was observed with subtilisin Novo. In addition, the bond $\mathrm{Arg}_{4}-\mathrm{Thr}_{5}$ is hydrolyzed quite readily.

\subsubsection{Clupein Z}

Because of the close similarity in sequence between the Z (see Fig. 7) and YII components of clupein, and since they were hydrolyzed with identical rates by subtilisin Novo, it was anticipated that the primary bonds to be hydrolyzed were also identical. This was confirmed by separation of hydrolytic peptides by ion-exchange chromatography, as shown in Fig. 6. As suspected, peak VI with the very high color-yield contained both $\mathrm{Ala}_{1}-\mathrm{Ser}_{22}$ and $\mathrm{Arg}_{23}$. $\operatorname{Arg}_{31}$. This was demonstrated by amino acid analysis of fractions from the ascending and descending limb, respectively, and by gelfiltration on Sephadex G25, whereby the two peptides were separated, followed by amino

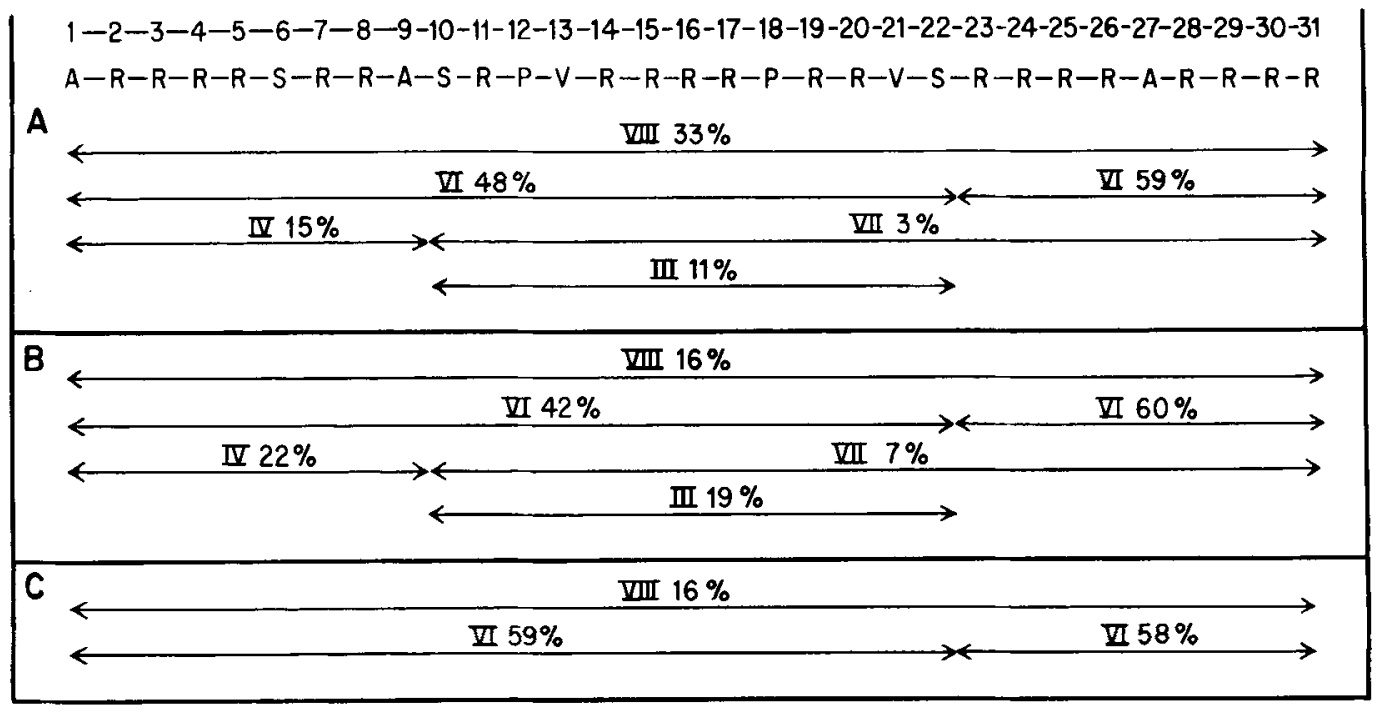


acid analysis. The unidentified peaks (I, II and v) accounted for less that $10 \%$ of recovered material.

The yields and peak number of assigned peptides are shown in Fig. 7, A. As expected, the bond $\mathrm{Ser}_{22}-\mathrm{Arg}_{23}$ was the one most readily hydrolyzed followed by $\mathrm{Ala}_{9}-\mathrm{Ser}_{10}$.

Chromatography of the hydrolytic peptides from clupein- $Z$ digested by subtilisin Carlsberg showed an elution pattern very similar to the one shown in Fig. 6. Also in this case, unidentified peaks contained less than $10 \%$ of the total material eluted. Fig. 7, B gives the yields and peak number of the assigned peptides. The bond $\mathrm{Ser}_{22}-\mathrm{Arg}_{23}$ is the most readily hydrolyzed followed by $\mathrm{Ala}_{9}-\mathrm{Ser}_{10}$. At $60 \%$ cleavage of the bond $\operatorname{Ser}_{22}-\operatorname{Arg}_{23}$ a $26 \%$ cleavage was observed at $\mathrm{Ala}_{\mathrm{g}}-\mathrm{Ser}_{10}$ with subtilisin Carlsberg, but only $15 \%$ with subtilisin Novo. Therefore, it appears that the bond $\mathrm{Ala}_{9}-\mathrm{Ser}_{10}$ is hydrolyzed faster by subtilisin Carlsberg than Novo relative to the bond cleavage at $\operatorname{Ser}_{22}-\operatorname{Arg}_{23}$.

\subsubsection{Clupein $Y^{I}$}

No final conclusions can be drawn with respect to the bonds preferentially hydrolyzed in clupein $\mathrm{Y}^{\mathrm{I}}$ by the subtilisins. Although wellseparated, bell-shaped peaks were eluted from the ion-exchange column with the gradient described in the method section, they appeared to be mixtures of peptides. Using a gradient ranging from 0 to $1.5 \mathrm{M}-\mathrm{NaCl}$ the elution pattern showed that several minor components were present. In this case it was possible to identify some of the liberated peptides, and the following bonds were shown to by hydrolyzed by both subtilisins: $\operatorname{Arg}_{5}-\operatorname{Ser}_{6}, \operatorname{Ser}_{6}-\operatorname{Ser}_{7}, \operatorname{Arg}_{15}-$ Pro $_{16}$, and $\mathrm{Thr}_{20}-\mathrm{Thr}_{21}$. A peak appearing early in the chromatogram contained only arginine and in large amounts. From the position in the elution pattern, $(\mathrm{Arg})_{2}$ or $(\mathrm{Arg})_{3}$ are the most likely forms of the liberated arginine.

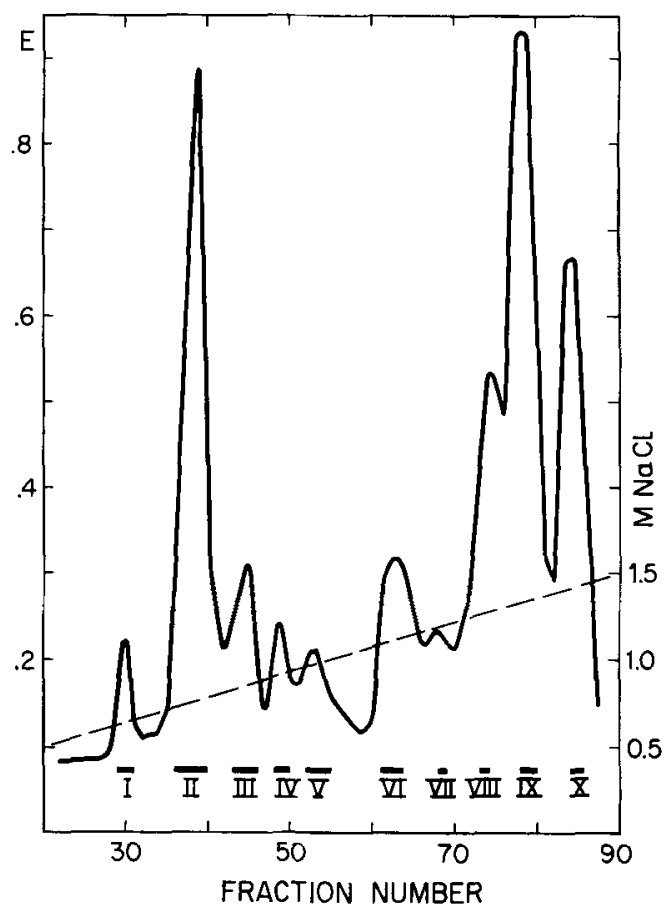

Figure 8. Chromatography of clupein $\mathrm{Y}$, digested with nitrated subtilisin Carlsberg, on Whatman CM $52(1 \times 120 \mathrm{~cm})$. Salt gradient from 0.5 to $1.5 \mathrm{M}-\mathrm{NaCl}$. Flow-rate $15 \mathrm{ml} / \mathrm{hr} .2 .5 \mathrm{ml}$ fractions collected. Room temperature. Abscisse: Fraction number. Left ordinate: $\mathrm{E}_{520 \mathrm{~nm}}$. Right ordinate: $\mathrm{NaCl}$ conc $(\mathrm{M})$. - - - salt gradient - fractions pooled for further analysis.

\subsubsection{Nitrated subtilisin Carlsberg}

When clupein- $Z$ was cleaved by nitrated subtilisin Carlsberg, ion-exchange chromatography showed an elution pattern very similar to the one shown in Fig. 6. However, the dominating peak (VI in Fig. 6) was larger, peak VIII of equal size, and the rest smaller. Only peaks VI

Figure 9. Compositions and yields (in per cent of material applied to the Whatman CM 52 column) of peptide fragments from digest of clupein YI with nitrated subtilisin Carlsberg.

$$
\begin{aligned}
& 1-2-3-4-5-6-7-8-9-10-11-12-13-14-15-16-17-18-19-20-21-22-23-24-25-26-27-28-29-30-31 \\
& A-R-R-R-R-S-S-S-R-P-I-R-R-R-R-P-R-R-R-T-T-R-R-R-R-A-G-R-R-R-R
\end{aligned}
$$

X $28 \%$

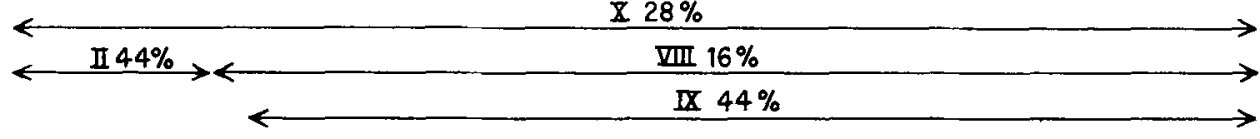


and VIII were analyzed further. The yields of the peptides are shown in Fig. 7, C.

Fig. 8 shows the elution pattern of peptides obtained by hydrolysis of clupein $\mathrm{Y}^{\mathrm{l}}$ by nitrated subtilisin Carlsberg. In this case, the column length was $120 \mathrm{~cm}$. The four peaks II, VIII, IX and $X$, which constitute the major portion of the eluted peptides, have all been identified. The peak number and per cent recovery of these peptides are shown in Fig. 9. Neither the peptide $\mathrm{Ala}_{1}-\mathrm{Ser}_{6}$ or a peak containing exclusively Arg, both of which were formed in the hydrolysis of $\mathrm{Y}^{\mathrm{I}}$ by native subtilisin Carlsberg or Novo, have been identified as products of hydrolysis by the nitrated enzyme.

\subsubsection{Potentiometric titrations}

Potentiometric titration of clupein sulfate showed that the N-terminal amino groups titrate with an average $\mathrm{pK}$ of 7.6. Using this value and the amount of clupein in the hydrolyzed solution, the base consumption during the experiment ( $2 \mu \mathrm{eq}$. in all experiments) indicate that 1.5 to 1.7 bond per molecule was hydrolyzed. This finding is in agreement with only two major cleavage-points being observed for clupein-Z and $\mathrm{Y}^{\mathrm{Il}}$. Many more bonds are hydrolyzed if the reaction mixture is left for a long time. For $\mathrm{Y}^{\mathrm{II}}$ chloride a total base-uptake of $10 \mu$ eq. was recorded for a $0.5 \%$ solution, corresponding to the cleavage of 8 bonds.

\section{DISCUSSION}

Clupein, a mixture of three protamines isolated from herring sperms, is a good substrate for subtilisin Novo. It has been shown from studies with ester substrates or small synthetic peptides that the subtilisins preferentially split bonds adjacent to Tyr, Phe or Leu (8). None of these amino acid residues are present in clupein which furthermore contains about $65 \%$ of the positively charged arginyl residues. Therefore, it was of interest to determine which bonds were hydrolyzed in this substrate by the subtilisins in order to get a better understanding of the importance of the secondary binding sites in these enzymes.

From studies of the hydrolysis of synthetic peptides of different length and composition,
MORIHARA and coworkers (8) have shown that at least six residues of the substrate come into contact with the surface of the subtilisins upon binding. Four of these are located on the $\mathrm{N}$ terminal side of the susceptible bond and two on the C-terminal side. This means, in the nomenclature of SCHECHTER and BERGER (14), that the subtilisins have at least six subsites $\left(S_{1}\right.$ to $S_{4}$ and $S_{1}^{\prime}, S_{2}{ }_{2}$ ). X-ray crystallographic studies by KRAUT and coworkers (13) have identified the part of the surface of subtilisin BPN' which constitutes subsites $S_{1}$ to $S_{4}$ for the synthetic peptides investigated. The preference for Tyr, Phe and Leu in $S_{1}$ was confirmed, and Ala was shown to be the ideal amino acid residue in $S_{2}$ since a larger side chain would get into too close contact with the enzyme. The side-chain accomodated in $S_{3}$ was not critical since it was pointing away from the enzyme. Finally, a hydrophobic side-chain is preferred by subsite $S_{4}$. The subsites $S_{1}^{\prime}$ and $S_{2}^{\prime}$ were not located by $\mathrm{X}$-ray analysis, but are considered to be hydrophobic in nature ("Sticky spotsu).

Studies of the rate of hydrolysis of the individual clupein components (clupein $\mathrm{Y}^{\mathrm{I}}$, YII and $Z$ ) have shown that clupein $\mathrm{Y}^{\mathrm{Il}}$ and $\mathrm{Z}$ are hydrolyzed by subtilisin Novo with identical rates and faster than $\mathrm{Y}^{\mathrm{I}}$. Clupein $\mathrm{YII}^{\mathrm{II}}$ and $\mathrm{Z}$ are nearly identical in sequences (see Fig. 10), and the bonds being hydrolyzed in the initial state of hydrolysis are identical in the two components. The first bond to be opened is $\operatorname{Ser}_{21}-\operatorname{Arg}_{22}$ in clupein $\mathrm{Y}^{\mathrm{II}}$ (which corresponds to $\mathrm{Ser}_{22}-\mathrm{Arg}_{23}$ in clupein $Z$ ). This is followed by $\mathrm{Ala}_{\mathbf{8}}-\mathrm{Ser}_{9}$ in clupein $\mathrm{Y}^{\mathrm{II}}\left(\mathrm{Ala}_{9}-\mathrm{Ser}_{10}\right.$ in clupein Z). Many more bonds can be hydrolyzed in the two components, but with a rate which is slow compared to that with which the two bonds just mentioned are opened.

No obvious correspondance is obtained between the conclusions about subsites made from X-ray crystallographic studies of subtilisin $\mathrm{BPN}^{\prime}$ and the sequence around the two bonds preferentially hydrolyzed in clupein $\mathrm{Y}^{\mathrm{II}}$ and $\mathrm{Z}$ by this enzyme. In both cases the preferred hydrolysis of the bond $\operatorname{Ser}_{21}-\mathrm{Arg}_{22}\left(\mathrm{Ser}_{22}-\mathrm{Arg}_{23}\right.$, respectively) places a Ser in $S_{1}$, a bulky Val in $S_{2}$, a positively charged Arg in $S_{4}$ and two positively charged Arg's in $S^{\prime}{ }_{1}$ and $S^{\prime}{ }_{2}$. Clupein $\mathrm{Y}^{\mathrm{I}}$ is hydrolyzed with a slower rate than 


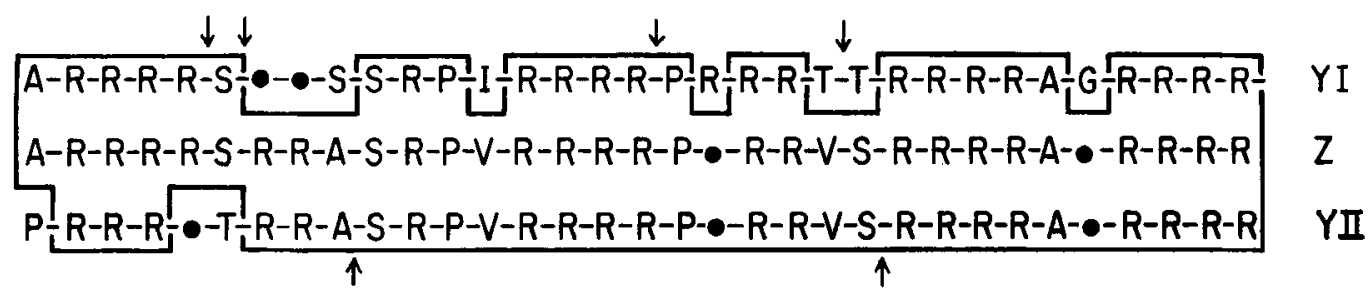

Figure 10. The amino acid sequence of clupein $Y, Z$ and YII arranged to give maximal homology. dicates presumed deletions. $\uparrow$ principal points of attack in clupein YII and $Z$. $\downarrow$ : points of attack in clupein $\mathrm{Y} \mathbf{1}$.

are the two other components. In addition, it appears that several bonds are hydrolyzed with about equal rates giving rise to a mixture of peptides not easily resolved on ion-exchange chromatography. Although the homology is close between $\mathrm{Y}^{\mathrm{I}}$ and the two other components (see Fig. 10), one of the differences is seen at the susceptible Ser-Arg bond in YII and $Z$. The equivalent bond in $Y^{I}$ is Thr-Arg. The close structural similarity between Ser and Thr argues against any major change in susceptibility to enzymatic attack. The replacement in subsite $\mathrm{S}_{2}$ of a Val in $\mathrm{Y}^{\mathrm{II}}$ or $\mathrm{Z}$ by a $\mathrm{Thr}$ in $\mathrm{Y}^{\mathrm{I}}$ may be more important since a hydrophilic residue is replaced by a hydrophobic one. The remaining four subsites $\left(S_{3}, S_{4}, S_{1}^{\prime}\right.$ and $\left.S_{2}^{\prime}\right)$ are occupied by identical residues $(\mathrm{Arg})$ in all three substrates and should not contribute to the difference in rate of hydrolysis. This difference could perhaps also be due to strong non-productive binding of $Y^{\mathrm{I}}$, but a detailed kinetic study of this possibility has not been attempted.

Subtilisin Carlsberg hydrolyzes the same two bonds in $\mathrm{Yll}^{\mathrm{II}}$ and $\mathrm{Z}$ as does subtilisin Novo although the rates with which they are opened are much slower. These results, therefore, confirm earlier studies (6) which indicated that the differences in the enzymatic activity between the two enzymes are quantitative rather than qualitative. Although a precise assignment of the peptides produced in the hydrolysis of Clupein $\mathrm{Y}^{\mathrm{I}}$ has not been possible, the similarity in elution-patterns from ion-exchange chromatography suggest that also in this case the differences in enzymatic activity between the two enzymes are quantitative.
It has previously been shown that nitration of $\mathrm{Tyr}_{104}$ in subtilisin Carlsberg results in a much faster rate of hydrolysis of clupein sulfate (17). When clupein- $Z$ is hydrolyzed by nitrated subtilisin Carlsberg, the same bonds are split as with the unmodified enzyme. However, the relative rate with which the bonds $\operatorname{Ser}_{22}-\operatorname{Arg}_{23}$ and $\mathrm{Ala}_{9}-\mathrm{Ser}_{10}$ are opened has, to a marked degree, changed in favor of the former. KRAUT and coworkers have shown that $\mathrm{Tyr}_{104}$ is part of subsite $\mathrm{S}_{4}$ in subtilisin $\mathrm{BPN}^{\prime}$ (identical to subtilisin Novo). A detailed $X$-ray crystallographic study of the Carlsberg enzyme has not yet been published but the close homology between the two subtilisins (20) strongly suggest that $\mathrm{Tyr}_{104}$ is part of $\mathrm{S}_{4}$ in subtilisin Carlsberg as well. (A model of subtilisin Carlsberg built in our laboratory from the coordinates for subtilisin $\mathrm{BPN}^{\prime}$ is compatible with this suggestion). Since the same bonds are hydrolyzed by unmodified and modified subtilisin Carlsberg in clupein- $Z$, it is reasonable to suggest that it is an already existing binding mode, the one suggested by KRAUT and coworkers, which has been improved.

It has been suggested (18) that the negative charge which is introduced at $\mathrm{pH} 8$ by nitration of $\mathrm{Tyr}_{104}$ interacts with a positive arginyl sidechain and in this way facilitates the binding of clupein. When $\operatorname{Ser}_{22}-\operatorname{Arg}_{23}$ is hydrolyzed, an arginyl side-chain will bind in subsite $S_{4}$, and thus enhance the rate of hydrolysis. In contrast, a seryl side-chain will bind to $\mathrm{S}_{4}$ when $\mathrm{Ala}_{9}-\mathrm{Ser}_{10}$ is hydrolyzed. Therefore, the hydrolysis of this bond should not be influenced by nitration of subtilisin Carlsberg, and the relative rates with which the two bonds are cleaved should change in favor of the $\operatorname{Ser}_{22}-\mathrm{Arg}_{23}$, which was found to be the case.

Hydrolysis of the bonds $\operatorname{Arg}_{5}-\operatorname{Ser}_{6}, \operatorname{Ser}_{6}-\mathrm{Ser}_{7}$, $\mathrm{Arg}_{15}-\mathrm{Pro}_{16}$ and $\mathrm{Thr}_{20}-\mathrm{Thr}_{21}$ which has been demonstrated in clupein $\mathrm{Y}^{\mathbf{I}}$ also takes place 
with an arginyl residues placed in $S_{4}$. The enhancement in rate of hydrolysis which takes place with clupein- $\mathrm{Y}^{\mathrm{I}}$ when subtilisin Carlsberg is nitrated thus can be explained, in part, in a similar way as for clupein- $Z$, since these bonds are also hydrolyzed by nitrated subtilisin Carlsberg.

As observed for clupein- $Z$ hydrolysis, a change in preference of certain bonds takes place upon nitration. The hydrolysis of $\operatorname{Arg}_{5}-\operatorname{Ser}_{6}$ takes place only to a very limited extent by the unmodified subtilisin Carlsberg, but becomes the major point of attack by nitrated subtilisin Carlsberg (see Fig. 9). In addition, the large amounts of $\operatorname{Arg}_{\mathrm{x}}$ liberated by the unmodified enzyme were not observed with the nitrated one.

The hydrolysis of all three clupein components involves bonds with serine as one of the donors (on either side). This may be more than a coincidence. Thus, when ovalbumin is transformed into plakalbumin, an Ala-Ser bond is broken $(9,19)$. When ribonuclease is transformed into ribonuclease-S, an Ala-Ser bond is split (12). It should be realized, naturally, that in these two cases the availability of these bonds are influenced by the folding of the proteins in the native state. Upon the complex formation between potato inhibitor II-b and subtilisin BPN', a Lys-Ser bond is cleaved in the inhibitor (4). Of the 10 bonds cleaved in glucagon by subtilisin Carlsberg (16), two involves a serine residue: Ser-Lys and Ser-Asp. When the Bchain of oxidized insulin is hydrolyzed by the subtilisins, a Ser-His bond is among the first bonds to be cleaved (6). Of the five bonds hydrolyzed in a peptide from lactic dehydrogenase, three involve serines: Ser-Gly, Asp-Ser and Ser-Ala (3). Finally, it should be mentioned that denatured subtilisin is an excellent substrate for native subtilisin. Since the enzymes contain many seryl residues ( 32 in the Carlsberg enzyme and 37 in subtilisin Novo), this may be the reason for the high rate of hydrolysis. Although many synthetic peptideand ester substrates have been used in the study of the enzymatic activity of the subtilisins none of these have included a Ser. Thus, it is not possible to evaluate the importance of this sidechain relative to f.ex. Tyr.
The hydrolysis of the clupein components as their sulfate salts is only slightly effected by the presence of $0.1 \mathrm{M}-\mathrm{NaCl}$. The corresponding chlorides, on the other hand, are hydrolyzed very slowly in distilled water, and addition of $0.1 \mathrm{M}-\mathrm{NaCl}$ was necessary to obtain rates of hydrolysis comparable to those of the sulfates. This difference probably reflects a difference in binding between the monovalent chloride-ion and the divalent sulfate-ion to the arginyl sidechains of clupein. Such a difference in ion-binding might lead to a difference in type of bonds being hydrolyzed by the subtilisins. To test this possibility, clupein-Z and $Y^{I}$ chlorides were converted to the corresponding sulfates and hydrolyzed with subtilisin Novo. Analysis of the resulting peptides showed that the same bonds were hydrolyzed in the initial stage as when the chlorides were hydrolyzed. Thus, the counterion does not influence the mode of binding of clupein- $Z$ and $Y^{l}$ to subtilisin Novo. The same is probably true for the binding of clupein sulfate to subtilisin Carlsberg.

When the B-chain of oxidized insulin is cleaved by the subtilisins, these enzymes show a strong preference for a single bond, $\operatorname{Leu}_{15}-\mathrm{Tyr}_{16}$ (6). The hydrolysis of this bond is adequately explained by the excellent fit between the residues around the susceptible bond and the subsites identified by KRAUT and coworkers (13). When clupein YII or Z are hydrolyzed, a similar preference is also demonstrated which, in the case of subtilisin Carlsberg, can be enhanced by nitration (17). The main purpose of the present investigation was to determine why a substrate which does not contain amino acid residues that are good candidates for occupying subsite $S_{1}$ (Tyr, Leu, Phe), nontheless is hydrolyzed rapidly by subtilisin Novo. It was surprising to find that the subtilisins have such strong preference for two bonds in clupein $\mathrm{YII}^{\mathrm{II}}$ and $\mathrm{Z}$ and that the specificity towards the Ser-Arg bond appears to be dictated by the presence of a Val in $\mathrm{P}_{2}$. The hydrolysis of AlaSer rather than the adjacent Ser-Arg is presumably due to the inability of $S_{2}$ to accomodate a Pro (see Fig. 10). These findings add further evidence to the importance of secondary binding sites for both binding and specificity. 


\section{ACKNOWLEDGEMENTS}

The author wishes to thank Professor MARTIN OTTESEN for stimulating discussions and helpful criticism. Also the skilled technical assistance of Miss Bodil CoRneliussen is grateful acknowledged as is the linguistic corrections made by Professor HENRY ABRASH.

\section{REFERENCES}

1. ANDO, T. \& K. SUZUKI: The amino acid sequence of the third component of clupein. Biochim. Biophys. Acta. 140: 375-377 (1967)

2. ANDo, T. \& S. Watanabe: A new method for fractionation of protamines and the amino acid sequences of one component of salmine and three components of iridine. Int. J. Protein Research : 221-224 (1969)

3. Holbrook, J. J., G. Pleiderer, J. SchnetGer \& S. Diemair: The importance of SH-groups for enzymatic activity. Biochem. Zeitschr. 344: 1-14 (1966)

4. IWAsaki, T., T. Kiyohara \& M. YoshiKawa: Identification of the reactive site of potato proteinase inhibitor II-b for bovine and a bacterial proteinase. J. Biochem. 74: 335-340 (1973)

5. Izumi, Y.: New Sakaguchi reaction. Anal. Biochem. 10: 218-226 (1965)

6. Johansen, J. T., M. Ottesen, I. Svendsen \& G. WYBRANDT: The degradation of the B-chain of oxidized insulin by two subtilisins and their succinylated and $\mathrm{N}$-carbamylated derivatives. Compt. Rend. Trav. Lab. Carlsberg 36: 365-384 (1968)

7. Morihara, K., T. OKa \& H. Tsuzuki: Subtilisin BPN': Kinetic studies with oligopeptides. Arch. Biochem. Biophys. 138: 515-525 (1970)

8. Morihara, K., H. Tsuzuki \& T. OKa: Comparison of various types of subtilisins: Size and properties of the active site. Biochem. Biophys. Res. Comm. 42: 1000-1006 (1971)
9. OTteSEN, M.: The transformation of ovalburmin into plakalbumin. Compt. Rend. Trav. Lab. Carlsberg, Ser. Chim. 30: 211-270 (1958)

10. Ottesen, M. \& A. Spector: A comparison of two proteinases from Bacillus subtilis. Compt. Rend. Trav. Lab. Carlsberg 32: 63-74 (1960)

11. OtTesen, M. \& I. Svendsen: The effect of salts on the enzymatic activity of subtilisin type Carlsberg and subtilisin type Novo. Compt. Rend. Trav. Lab. Carlsberg 38: 369-383 (1971)

12. Richards, F. M. \& P. J. VithayathIL: The preparation of subtilisin-modified ribonuclease and the separation of the peptide of bovine pancreatic ribonuclease A. J. Biol. Chem. 234: 14591465 (1959)

13. Robertus, J. D., R. A. Alden, J. J. Birktoft, J. Kraut, J. S. Powers \& P. E. Wilcox: An X-ray crystallographic study of the binding of peptide chloromethyl ketone inhibitors to subtilisin BPN'. Biochemistry 11: 2439-2449 (1972)

14. Schechter, I. \& A. Berger: On the size of the active site in proteass. Biochem. Biophys. res. Comm. 27: 157-162 (1967)

15. SChmiedeberg, O.: Uber die Nucleinsäure aus Lachsmilch. Arch. Exp. Pathlogie und Pharmakologie 43: 57 (1899)

16. SinN, L. G., O. K. Behrens \& W. W. Bromer: The amino acid sequence of glucagon. The hydrolysis of glucagon with subtilisin. J. Amer. Chem. Soc. 79: 2805-2807 (1957)

17. Svendsen, I.: Chemical derivatives of subtilisins with modified proteolytic activities. I. Nitration and iodination of subtilisin type Carisberg and subtilisin type Novo. Compt. Rend. Trav. Lab. Carlsberg 36: 347-363 (1968)

18. SVENDSEN, I.: Identification of the 3-nitrotyrosyl residues in subtilisin type Carlsberg treated with tetranitromethane. Compt. Rend. Trav. Lab. Carlsberg 39: 375-398 (1974)

19. Thompson, E. O. P., R. W. Sleight \& M. B. SMITH: Amino acid sequence of the large plakalbumin peptide and the carboxyl terminal sequence of ovalbumin. Aust. J. Biol. Sci. 24: 525-534 (1971)

20. Wright, C. S., R. A. Alden \& J. Kraut: Structure of subtilisin BPN' at $2.5 \AA$ resolution, Nature 221: 235-242 (1969) 